Consumer Views on Transportation and Energy (Second Edition)

M. Kubik
Technical Report NREL/TP-620-36785 April 2005 


\section{Consumer Views on Transportation and Energy (Second Edition)}

M. Kubik

Prepared under Task No(s). ASA5.1315

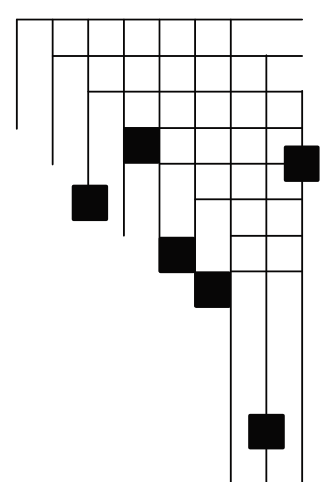




\section{NOTICE}

This report was prepared as an account of work sponsored by an agency of the United States government. Neither the United States government nor any agency thereof, nor any of their employees, makes any warranty, express or implied, or assumes any legal liability or responsibility for the accuracy, completeness, or usefulness of any information, apparatus, product, or process disclosed, or represents that its use would not infringe privately owned rights. Reference herein to any specific commercial product, process, or service by trade name, trademark, manufacturer, or otherwise does not necessarily constitute or imply its endorsement, recommendation, or favoring by the United States government or any agency thereof. The views and opinions of authors expressed herein do not necessarily state or reflect those of the United States government or any agency thereof.

Available electronically at http://www.osti.gov/bridge

Available for a processing fee to U.S. Department of Energy and its contractors, in paper, from:

U.S. Department of Energy

Office of Scientific and Technical Information

P.O. Box 62

Oak Ridge, TN 37831-0062

phone: 865.576 .8401

fax: 865.576 .5728

email: mailto:reports@adonis.osti.gov

Available for sale to the public, in paper, from:

U.S. Department of Commerce

National Technical Information Service

5285 Port Royal Road

Springfield, VA 22161

phone: 800.553.6847

fax: 703.605.6900

email: orders@ntis.fedworld.gov

online ordering: http://www.ntis.gov/ordering.htm 


\section{TABLE OF CONTENTS}

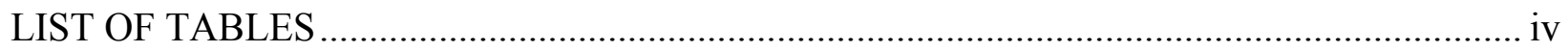

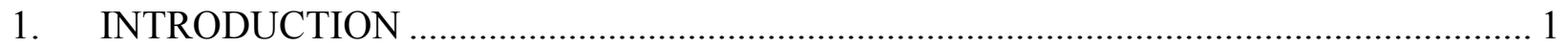

2. ENERGY, OIL, AND POLICY ............................................................................ 2

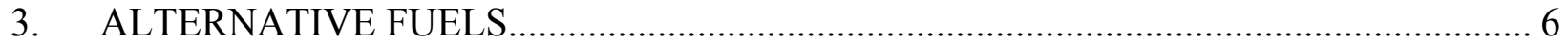

4. CONVENTIONAL, MORE FUEL-EFFICIENT, AND ADVANCED-TECHNOLOGY

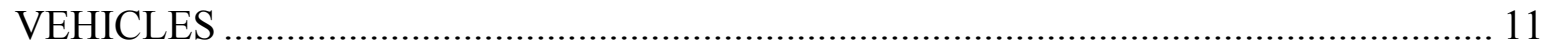

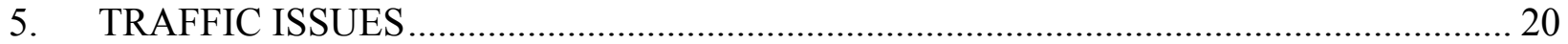




\section{LIST OF TABLES}

Table

Page

2.1.1 Public Perception of U.S. Vulnerability to Energy Crisis (1998) .....................................2

2.1.2 Seriousness of Energy Situation (selected years, 1977-2004) ...........................................2

2.2.1 Gas Price Increase - Effect on Lifestyle (June 2004) ......................................................

2.2.2 Gas Price Increase - Perceived Cause (May 2004) .........................................................

2.2.3 Gas Price Increase - Effect on Finances (selected years, 2000-2004) ...............................4

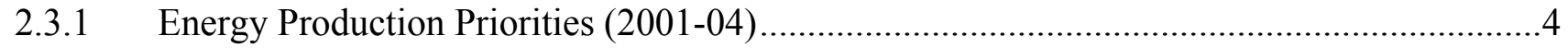

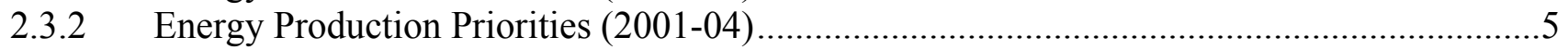

2.3.3 Environmental Proposals (March 2003) ….....................................................................

3.1.1 Factors Considered "Extremely Important" or "Very Important" in Influencing Decisions

to Try a New Fuel Technology (2003) ................................................................................6

3.1.2 Public Perception of Best Fuel and Worst Fuel for Use in Personal Vehicles When

Gasoline Is No Longer Available (2000 and 2004) ....................................................6

3.1.3 Reasons Electricity Would Be the Best Fuel for Use in Personal Vehicles When Gasoline Is No Longer Available (2000 and 2004) ....................................................................... 7

3.1.4 Reasons Ethanol Would Be the Best Fuel for Use in Personal Vehicles When Gasoline Is No Longer Available (2000 and 2004) ......................................................................8

3.1.5 Reasons Hydrogen Would Be the Best Fuel for Use in Personal Vehicles When Gasoline Is No Longer Available (2000 and 2004) ..................................................................... 8

3.1.6 Reasons Electricity Would Be the Worst Fuel for Use in Personal Vehicles When Gasoline Is No Longer Available (2000 and 2004) ......................................................9

3.1.7 Reasons Ethanol Would Be the Worst Fuel for Use in Personal Vehicles When Gasoline Is No Longer Available (2000 and 2004) ....................................................................9

3.1.8 Reasons Hydrogen Would Be the Worst Fuel for Use in Personal Vehicles When Gasoline Is No Longer Available (2000 and 2004) ............................................................... 10

4.1.1 Trends in Vehicle-Attribute Preference (selected years, 1980-2004)..............................11

4.1.2 Issue Is a Major Reason for Those NOT Considering the Purchase of an SUV (2003).......11

4.2.1 Number of Years Public is Willing to Accept for Payback of Higher Fuel-Economy Vehicle (2002) .....................................................................................................12

4.2.2 Additional Amount the Public is Willing to Pay for a Vehicle with a 10 Percent Increase in Fuel Economy (2001) .......................................................................................... 12

4.2.3 Public Preference Toward Purchasing a More Fuel-Efficient Engine with Different FuelAvailability Options (2000) ............................................................................. 13

4.3.1 Amount of Information Heard Pertaining to Advanced Hybrid-Electric Power Trains

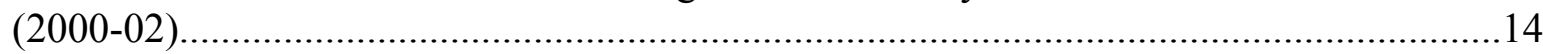

4.3.2 Names of Advanced Hybrid-Electric Vehicles Known by the Public (selected years,

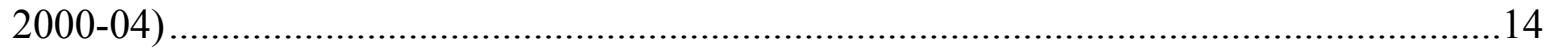

4.3.3 Public's Attitudes Toward Hybrid-Electric SUVs (2003) ............................................15

4.3.4.1 Public's Willingness to Consider the Purchase of a Diesel Engine With a 40 Percent Increase in Fuel Economy and Additional Costs of \$1,500 (1997).................................16

4.3.4.2 Public's Willingness to Pay a Premium for a Clean Diesel Engine (2002).......................16

4.3.5 Purchase Preference Between Diesel and Gasoline Vehicles by Vehicle Type (2001) .......17

4.3.6 Reasons for Choosing a Diesel Option (2001) ...........................................................17 


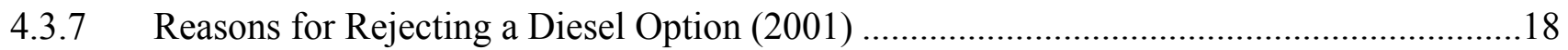

4.3.8 Vehicle-Purchase Preferences (2004) ...........................................................................

4.3.9 Vehicle-Purchase Preferences - Diesel vs. Hybrid-electric (2004) .....................................19

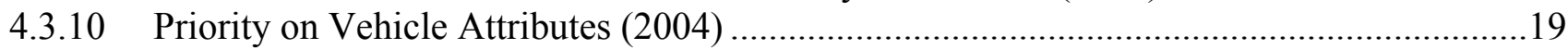

5.1 Public Ranking of the Most Irritating Part of Driving (2002) ............................................20

5.2 Most Important Reasons for Travel Delays (2000) .........................................................20

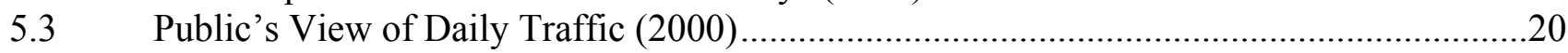

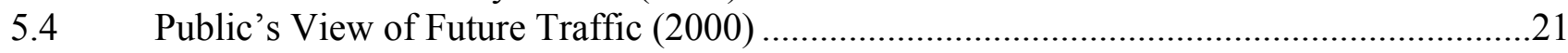

5.5.1 Have Changed Schedule Because of Traffic (2000)...........................................................21

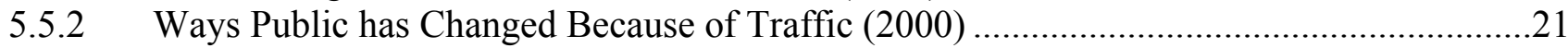

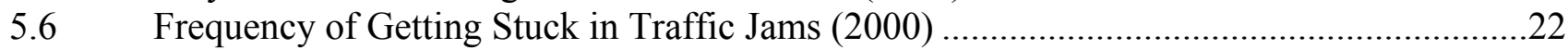

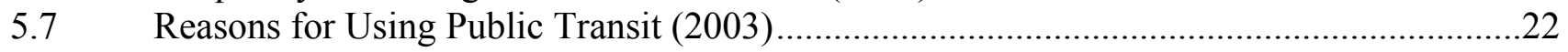




\section{INTRODUCTION}

This report was written to provide the Office of Energy Efficiency and Renewable Energy (EERE) with an idea of how the American public views various transportation, energy, and environmental issues.

The data presented in this report have been drawn from multiple sources: surveys conducted by the Opinion Research Corporation (ORC) for the National Renewable Energy Laboratory (NREL) that are commissioned and funded by EERE, Gallup polls, news organization polls, surveys conducted by independent groups, and other sources. Most of the surveys are telephone interviews conducted with randomly selected national samples of adults 18 and older (some were done via the Internet). The surveys use national samples, and the sample size is noted, wherever it is available. The surveys were selected based on their relevance to this overall topic.

The Consumer Views on Transportation and Energy report consists of five sections, including the introduction (Section 1). Section 2 examines public concern about U.S. dependence on imported oil and public assessment of the energy situation in the United States. Section 2 also examines public beliefs about actions to address energy problems, as well as actual and perceived effects of gasoline prices on individuals and households.

Section 3 analyzes what Americans think about alternative fuels such as electricity, ethanol, hydrogen, and other fuel types. Section $\mathbf{4}$ focuses on conventional and advanced-technology vehicles. In this report, advanced-technology vehicles include hybrid-electric and diesel vehicles. Section 4 also analyzes owners' decisions about purchasing more fuel-efficient vehicles and advanced-technology vehicles. Section 5 looks at the public's perception of on-road travel and traffic congestion.

In this edition of Consumer Views on Transportation and Energy, ORC and Gallup poll results for 2002, 2003, and 2004 have been included. ORC surveys were conducted in March 2002, November 2002, March 2003, and twice in 2004 (May and August). The new Gallup polls were conducted throughout 2004. ORC and Gallup asked some of the same energy and environment questions during the past several years. The latest results have been added to the prior ones to show the most current opinions and trends during the past several years.

The report also features new questions from both ORC and Gallup. These 2004 surveys examined "hot" topics such as gas-price increases, environmental issues, and vehicle-purchase preferences. 


\section{ENERGY, OIL, AND POLICY}

Public opinion polls reveal that the U.S. public perceives the country's energy situation as a serious issue (Table 2.1.2). This section examines the public's assessment of the energy situation, actual and perceived effects of gasoline prices on driving, and public beliefs about actions to address energy problems.

\subsection{PUBLIC ASSESSMENT OF THE ENERGY SITUATION}

Q2.1.1: The United States imports about half of its oil from foreign sources - more than it did 25 years ago. Based on this fact, how vulnerable do you believe the United States is to an energy crisis that would be caused by foreign nations shutting off their supply of oil to the United States: very, somewhat, not too, not at all?

Table 2.1.1. Public Perception of U.S. Vulnerability to Energy Crisis (1998)

\begin{tabular}{|l|c|}
\hline Categories of Responses & Percent \\
\hline Very vulnerable & 47 \\
\hline Somewhat vulnerable & 36 \\
\hline Not too vulnerable & 12 \\
\hline Not at all vulnerable & 3.5 \\
\hline Don't know/refused & 1.5 \\
\hline Total & 100 \\
\hline
\end{tabular}

Source: Research/Strategy/Management Inc. (1998), N=1,003

Q2.1.2 How serious would you say the energy situation is in the United States - very serious, fairly serious, or not at all serious?

Table 2.1.2. Seriousness of Energy Situation (selected years, 1977-2004)

\begin{tabular}{|l|c|c|c|c|}
\hline Date & $\begin{array}{c}\text { Very serious } \\
(\mathbf{\% )}\end{array}$ & $\begin{array}{c}\text { Fairly } \\
\text { serious (\%) }\end{array}$ & $\begin{array}{c}\text { Not at all } \\
\text { serious (\%) }\end{array}$ & No opinion \\
\hline March 2004 & 29 & 57 & 12 & 2 \\
\hline March 2003 & 28 & 59 & 11 & 2 \\
\hline March 2002 & 22 & 63 & 12 & 3 \\
\hline March 2001 & 31 & 59 & 9 & 1 \\
\hline Feb. 1991 & 40 & 44 & 14 & 2 \\
\hline Aug. 1990 & 28 & 45 & 23 & 4 \\
\hline April 1979 & 44 & 36 & 16 & 4 \\
\hline March 1978 & 41 & 39 & 15 & 5 \\
\hline April 1977 & 44 & 40 & 11 & 5 \\
\hline
\end{tabular}

Source: Gallup (selected years, 1977-2004), N=496 


\subsection{ACTUAL AND PERCEIVED EFFECTS OF GASOLINE PRICES ON DRIVING}

Among those who responded to questions related to this section, it was clear that increases in gas prices affects driving habits and lifestyle traits. This is consistent with data showing that when gasoline prices are lower, people tend to use their vehicles more; and conversely, when gasoline prices increase, driving declines (Table 2.2.1).

Q2.2.1: As a result of the recent rise in gas prices, would you say you have - or have not done each of the following?

Table 2.2.1. Gas Price Increase - Effect on Lifestyle (June 2004)

\begin{tabular}{|l|c|c|c|}
\hline Lifestyle trait & $\begin{array}{c}\text { Yes, have } \\
(\mathbf{\%})\end{array}$ & $\begin{array}{c}\text { No, have not } \\
(\mathbf{\%})\end{array}$ & $\begin{array}{c}\text { No opinion } \\
(\%)\end{array}$ \\
\hline $\begin{array}{l}\text { Made more of an effort to find the gas station } \\
\text { with the cheapest gas in your area }\end{array}$ & 69 & 30 & 1 \\
\hline $\begin{array}{l}\text { Seriously considered getting a more fuel- } \\
\text { efficient car the next time you buy a vehicle }\end{array}$ & 53 & 46 & 1 \\
\hline Cut back significantly on how much you drive & 45 & 54 & 1 \\
\hline $\begin{array}{l}\text { Cut back significantly on your household } \\
\text { spending because of the higher gas prices }\end{array}$ & 34 & 66 & $*$ \\
\hline Altered your summer vacation plans & 29 & 70 & 1 \\
\hline
\end{tabular}

Source: Gallup (June 3-6, 2004), N=465

Q2.2.2: Just your opinion, why would you say the price of gasoline has been increasing so much in recent months? (open-ended question)

Table 2.2.2. Gas Price Increase - Perceived Cause (May 2004)

\begin{tabular}{|l|c|}
\hline Price factor & Percent \\
\hline Big business/oil companies/price gouging/refineries want more profit & 22 \\
\hline The war in Iraq & 19 \\
\hline OPEC/Saudi Arabia manipulating supply & 9 \\
\hline Supply and demand & 8 \\
\hline Government/politics & 7 \\
\hline President Bush & 5 \\
\hline Lack of U.S. refining capability/lack of supply/drilling & 4 \\
\hline Gas shortage/lack of production & 4 \\
\hline Unrest in the Middle East & 4 \\
\hline Economy/inflation & 2 \\
\hline Summer vacation time/prices always go up around this time & 2 \\
\hline Foreign policy & 1 \\
\hline Other & 6 \\
\hline No opinion & 15 \\
\hline
\end{tabular}

Source: Gallup (May 21-23, 2004), N=496

Note: Percentages do not total 100, because each respondent could volunteer more than one response. 
Q2.2.3: Have recent price increases in gasoline caused any financial hardship for you or your household?

Table 2.2.3. Gas Price Increase - Effect on Finances (selected years, 2000-2004)

\begin{tabular}{|l|c|c|c|}
\hline Timeframe & $\begin{array}{c}\text { Yes, caused } \\
\text { hardship } \\
\mathbf{( \% )}\end{array}$ & $\begin{array}{c}\text { No, has not } \\
\text { caused } \\
\text { hardship } \\
\mathbf{( \% )}\end{array}$ & $\begin{array}{c}\text { No opinion } \\
\mathbf{( \% )}\end{array}$ \\
\hline May 21-23, 2004 & 47 & 52 & 1 \\
\hline Feb. 17-19, 2003 & 35 & 65 & $*$ \\
\hline May 7-9, 2001 & 47 & 53 & $*$ \\
\hline May 23-24, 2000 & 36 & 64 & $*$ \\
\hline
\end{tabular}

Source: Gallup (selected years, 2000-04), N=465

\subsection{PUBLIC BELIEFS ABOUT ACTIONS TO ADDRESS ENERGY PROBLEMS}

Q2.3.1: Which of the following approaches to solving the nation's energy problems do you think the United States should follow right now:

Emphasize production of more oil, gas, and coal supplies OR

Emphasize more conservation by consumers of existing energy supplies.

Table 2.3.1. Energy Production Priorities (2001-04)

\begin{tabular}{|l|c|c|c|c|c|}
\hline Date & $\begin{array}{c}\text { More } \\
\text { production }\end{array}$ & $\begin{array}{c}\text { More } \\
\text { conservation }\end{array}$ & $\begin{array}{c}\text { Both/equally } \\
\text { (vol.) }\end{array}$ & $\begin{array}{c}\text { Neither/other } \\
\text { (vol.) }\end{array}$ & $\begin{array}{c}\text { No } \\
\text { opinion }\end{array}$ \\
\hline March 2004 & 31 & 59 & 6 & 2 & 2 \\
\hline March 2003 & 29 & 60 & 7 & 2 & 2 \\
\hline March 2002 & 30 & 60 & 6 & 2 & 2 \\
\hline March 2001 & 33 & 56 & 8 & 1 & 2 \\
\hline
\end{tabular}

Source: Gallup (2001-04), N=496 
Q2.3.2: With which one of these statements about the environment and energy production do you most agree:

Protection of the environment should be given priority, even at the risk of limiting the amount of energy supplies (such as oil, gas, and coal), which the United States produces OR

Development of U.S. energy supplies (such as oil, gas and coal) should be given priority, even if the environment suffers to some extent.

Table 2.3.2. Energy Production Priorities (2001-04)

\begin{tabular}{|l|c|c|c|c|c|}
\hline Date & Environment & $\begin{array}{c}\text { Development } \\
\text { of energy } \\
\text { supplies }\end{array}$ & $\begin{array}{c}\text { Both/equally } \\
\text { (vol.) }\end{array}$ & $\begin{array}{c}\text { Neither/other } \\
\text { (vol.) }\end{array}$ & $\begin{array}{c}\text { No } \\
\text { opinion }\end{array}$ \\
\hline March 2004 & 48 & 44 & 3 & 1 & 4 \\
\hline March 2003 & 49 & 40 & 5 & 2 & 4 \\
\hline March 2002 & 52 & 40 & 3 & 2 & 3 \\
\hline March 2001 & 52 & 36 & 6 & 2 & 4 \\
\hline
\end{tabular}

Source: Gallup (2001-04), N=496

Q2.3.3: I am going to read some specific environmental proposals. For each one, please say whether you generally favor or oppose it.

Table 2.3.3. Environmental Proposals (March 2003)

\begin{tabular}{|l|c|c|c|}
\hline Proposal & Favor (\%) & $\begin{array}{c}\text { Oppose } \\
(\%)\end{array}$ & No opinion \\
\hline $\begin{array}{l}\text { Setting higher emissions and pollution } \\
\text { standards for business and industry }\end{array}$ & 80 & 19 & 1 \\
\hline $\begin{array}{l}\text { Imposing mandatory controls on carbon } \\
\text { dioxide emissions and other greenhouse gases }\end{array}$ & 75 & 22 & 3 \\
\hline $\begin{array}{l}\text { More strongly enforcing federal environmental } \\
\text { regulations }\end{array}$ & 75 & 21 & 4 \\
\hline $\begin{array}{l}\text { Setting higher auto emissions standards for } \\
\text { automobiles }\end{array}$ & 73 & 24 & 6 \\
\hline Expanding the use of nuclear energy & 43 & 51 & 4 \\
\hline $\begin{array}{l}\text { Opening up the Arctic National Wildlife } \\
\text { Refuge in Alaska for oil exploration }\end{array}$ & 41 & 55 & \\
\hline
\end{tabular}

Source: Gallup (March 2003), N=526 


\section{ALTERNATIVE FUELS}

A number of surveys researched the U.S. adult population knowledge and opinions about alternative types of fuel such as electricity, ethanol, and hydrogen. Poll questions asked between 2000 and 2004 focused on knowledge and opinions about alternative fuels. Several of these survey questions demonstrate that opinions regarding safety and environmental attributes of these fuel sources have changed from 2000 to 2004.

Table 3.1.1. Factors Considered "Extremely Important" or "Very Important" in Influencing Decisions to Try a New Fuel Technology (2003)

\begin{tabular}{|l|c|}
\hline Factor & Percent \\
\hline How safe the fuel is for drivers and passengers & 83 \\
\hline The cost of the fuel & 78 \\
\hline How far you can drive before refueling & 75 \\
\hline The cost of the vehicle & 72 \\
\hline The convenience of refueling & 67 \\
\hline Environmental emissions & 67 \\
\hline Whether the fuel source is domestic instead of foreign & 47 \\
\hline How the new fuel system affects passenger and cargo space & 47 \\
\hline Whether or not the fuel can be recycled & 45 \\
\hline
\end{tabular}

Source: Harris poll for Millennium Cell and U.S. Borax Inc. (2003), N=1,006.

Q3.1.2: Consider a future date when gasoline is no longer available. Which of the following do you think would be the best fuel for use in personal vehicles: electricity, ethanol, or hydrogen?

Table 3.1.2. Public Perception of Best Fuel and Worst Fuel for Use in Personal Vehicles When Gasoline Is No Longer Available (2000 and 2004)

\begin{tabular}{|l|r|r|r|r|}
\hline $\begin{array}{l}\text { Fuel for Use in } \\
\text { Personal Vehicles }\end{array}$ & \multicolumn{2}{|c|}{$\begin{array}{c}\text { Best Fuel } \\
\text { (percent) }\end{array}$} & \multicolumn{2}{c|}{$\begin{array}{c}\text { Worst Fuel } \\
\text { (percent) }\end{array}$} \\
\hline & $\mathbf{2 0 0 0}$ & $\mathbf{2 0 0 4}$ & $\mathbf{2 0 0 0}$ & $\mathbf{2 0 0 4}$ \\
\hline Electricity & 52 & 41 & 15 & 21 \\
\hline Hydrogen & 15 & 28 & 27 & 23 \\
\hline Ethanol & 21 & 19 & 28 & 28 \\
\hline Don't know & 12 & 13 & 30 & 29 \\
\hline Total & 100 & 100 & 100 & 100 \\
\hline
\end{tabular}

Source: ORC for NREL (2000b), Study No. 709489, N=1,000; and ORC for NREL (2004b), Study No. 713359, N=1,000. 
Q3.1.3: Why did you say electricity would be the best fuel for use in personal vehicles when gasoline is no longer available?

Table 3.1.3. Reasons Electricity Would Be the Best Fuel for Use in Personal Vehicles When Gasoline Is No Longer Available (2000 and 2004)

\begin{tabular}{|l|r|r|}
\hline \multirow{2}{*}{ Reasons } & \multicolumn{2}{|c|}{ Percent } \\
\cline { 2 - 3 } & $\mathbf{2 0 0 0}$ & $\mathbf{2 0 0 4}$ \\
\hline $\begin{array}{l}\text { Environmental concerns (cleaner, less pollution, cleaner air, other } \\
\text { environmental mentions) }\end{array}$ & 29 & 23 \\
\hline $\begin{array}{l}\text { Availability (abundant, common, renewable/inexhaustable, easy } \\
\text { to produce/manufacture, not dependent on foreign oil) }\end{array}$ & 22 & 23 \\
\hline $\begin{array}{l}\text { Existing/developing technology (electric cars already being } \\
\text { developed, technology already being used, many things powered } \\
\text { by electricity) }\end{array}$ & & \\
\hline Economical/affordable & 17 & \\
\hline $\begin{array}{l}\text { Methods of generating (can be solar generated/powered, other } \\
\text { related mentions) }\end{array}$ & 11 & \\
\hline Most familiar with it/not familiar with others & & \\
\hline Safe & 7 & 7 \\
\hline Best source & 7 & \\
\hline More efficient & 5 & \\
\hline Easier/convenient (unspecified) & 4 & \\
\hline Others not practical /performance concerns & 3 & 4 \\
\hline Other & 3 & \\
\hline Don't know & 3 & 2 \\
\hline
\end{tabular}

Source: ORC for NREL (2000b), Study No. 709489, N=522; and ORC for NREL (2004b), Study No. $713359, \mathrm{~N}=1,000$.

Note: Percentages do not total 100, because each respondent could volunteer more than one response. 
Q3.1.4: Why did you say ethanol would be the best fuel for use in personal vehicles when gasoline is no longer available?

Table 3.1.4. Reasons Ethanol Would Be the Best Fuel for Use in Personal Vehicles When Gasoline Is No Longer Available (2000 and 2004)

\begin{tabular}{|l|r|r|}
\hline \multirow{2}{*}{ Reasons } & \multicolumn{2}{|c|}{ Percent } \\
\cline { 2 - 3 } & $\mathbf{2 0 0 0}$ & $\mathbf{2 0 0 4}$ \\
\hline $\begin{array}{l}\text { Readily available (common, abundant, renewable/inexhaustible, easy } \\
\text { to produce/manufacture, can generate our own fuel, other mentions) }\end{array}$ & 27 & \\
\hline Methods of generating (made from corn/grain, other related mentions) & 18 & 28 \\
\hline Economical/affordable & 15 & 12 \\
\hline $\begin{array}{l}\text { Environmental concerns (cleaner, less pollution, other related } \\
\text { mentions) }\end{array}$ & 15 & \\
\hline Others not practical/performance concerns & 10 & 15 \\
\hline Better for/helps farmers/ farming industry & 8 & 6 \\
\hline Existing/developing technology & 8 & 14 \\
\hline Best source (unspecified) & 5 & 9 \\
\hline More similar to gasoline & 5 & 6 \\
\hline Other & 12 & 5 \\
\hline Don't know & 7 & 12 \\
\hline
\end{tabular}

Source: ORC for NREL (2000b), Study No. 709489, N=206; and ORC for NREL (2004b), Study No. $713359, \mathrm{~N}=1,000$.

Note: Percentages do not total 100, because each respondent could volunteer more than one response.

Q3.1.5: Why did you say hydrogen would be the best fuel for use in personal vehicles when gasoline is no longer available?

Table 3.1.5. Reasons Hydrogen Would Be the Best Fuel for Use in Personal Vehicles When Gasoline Is No Longer Available (2000 and 2004)

\begin{tabular}{|l|r|r|}
\hline \multirow{2}{*}{ Reasons } & \multicolumn{2}{|c|}{ Percent } \\
\cline { 2 - 3 } & $\mathbf{2 0 0 0}$ & $\mathbf{2 0 0 4}$ \\
\hline Availability (common, abundant, easy to produce/manufacture, & & \\
renewable/inexhaustible, other related mentions) & 37 & 36 \\
\hline Environmental concerns (cleaner, less pollution, other related mentions) & 27 & 24 \\
\hline Economical/affordable & 12 & 16 \\
\hline Others not practical/ performance concerns & 11 & 6 \\
\hline Existing/developing technology (net) & 7 & 6 \\
\hline More efficient & 5 & 1 \\
\hline Safety concerns & 5 & 1 \\
\hline Best source (unspecified) & 3 & 2 \\
\hline Other & 9 & 9 \\
\hline Don't know & 9 & 8 \\
\hline
\end{tabular}

Source: ORC for NREL (2000b), Study No. 709489, N=151; and ORC for NREL (2004b), Study No. $713359, \mathrm{~N}=1,000$.

Note: Percentages do not total 100, because each respondent could volunteer more than one response. 
Q3.1.6: Why did you say electricity would be the worst fuel for use in personal vehicles when gasoline is no longer available?

Table 3.1.6. Reasons Electricity Would Be the Worst Fuel for Use in Personal Vehicles When Gasoline Is No Longer Available (2000 and 2004)

\begin{tabular}{|l|r|r|}
\hline \multirow{2}{*}{ Reasons } & \multicolumn{2}{|c|}{ Percent } \\
\cline { 2 - 3 } & $\mathbf{2 0 0 0}$ & $\mathbf{2 0 0 4}$ \\
\hline Too expensive & 28 & 23 \\
\hline Electric vehicles can't hold charge for long/can't travel long distances & 20 & 9 \\
\hline $\begin{array}{l}\text { Environmental concerns (must burn coal/fossil fuels, pollution, other } \\
\text { related mentions) }\end{array}$ & 19 & \\
\hline Not enough electricity now & 12 & 23 \\
\hline Safety concerns & 5 & 2 \\
\hline Other & 15 & 9 \\
\hline Don't know & 10 & 13 \\
\hline
\end{tabular}

Source: ORC for NREL (2000b), Study No. 709489, N=150; and ORC for NREL (2004b), Study No. $713359, \mathrm{~N}=1,000$.

Note: Percentages do not total 100, because each respondent could volunteer more than one response.

Q3.1.7: Why did you say ethanol would be the worst fuel for use in personal vehicles when gasoline is no longer available?

Table 3.1.7. Reasons Ethanol Would Be the Worst Fuel for Use in Personal Vehicles When Gasoline Is No Longer Available (2000 and 2004)

\begin{tabular}{|l|r|r|}
\hline \multirow{2}{*}{ Reasons } & \multicolumn{2}{|c|}{ Percent } \\
\cline { 2 - 3 } & $\mathbf{2 0 0 0}$ & $\mathbf{2 0 0 4}$ \\
\hline $\begin{array}{l}\text { Environmental concerns (pollution, creates environmental } \\
\text { problems, other related mentions) }\end{array}$ & 38 & \\
\hline $\begin{array}{l}\text { Safety concerns (flammable/combustible, explosive, contains } \\
\text { chemicals, other related mentions) }\end{array}$ & 20 & 30 \\
\hline Too expensive & 6 & 12 \\
\hline Lack of availability & 4 & 4 \\
\hline Finite/exhaustible resource & 3 & 4 \\
\hline Difficult to produce & 3 & 2 \\
\hline Causes engine trouble & 3 & 3 \\
\hline Other & 13 & 1 \\
\hline Don't know & 20 & 7 \\
\hline
\end{tabular}

Source: ORC for NREL (2000b), Study No. 709489, N=281; and ORC for NREL (2004b), Study No. $713359, \mathrm{~N}=1,000$.

Note: Percentages do not total 100, because each respondent could volunteer more than one response. 
Q3.1.8: Why did you say hydrogen would be the worst fuel for use in personal vehicles when gasoline is no longer available?

Table 3.1.8. Reasons Hydrogen Would Be the Worst Fuel for Use in Personal Vehicles When Gasoline Is No Longer Available (2000 and 2004)

\begin{tabular}{|l|r|r|}
\hline \multirow{2}{*}{ Reasons } & \multicolumn{2}{|c|}{ Percent } \\
\cline { 2 - 3 } & $\mathbf{2 0 0 0}$ & $\mathbf{2 0 0 4}$ \\
\hline $\begin{array}{l}\text { Safety concerns (explosive, flammable/combustible, unstable, think of } \\
\text { bombs, other related mentions) }\end{array}$ & 50 & \\
\hline Pollution and environmental concerns & 8 & 40 \\
\hline Not enough is known about it & 4 & 5 \\
\hline Difficult to produce & 4 & 4 \\
\hline Too expensive & 3 & 1 \\
\hline Other & 15 & 9 \\
\hline Don't know & 21 & 23 \\
\hline
\end{tabular}

Source: ORC for NREL (2000b), Study No. 709489, N=274; and ORC for NREL (2004b), Study No. $713359, \mathrm{~N}=1,000$. 


\section{CONVENTIONAL, MORE FUEL-EFFICIENT, AND ADVANCED- TECHNOLOGY VEHICLES}

Section 4 focuses on vehicle owners and the decisions they make about their vehicles. It consists of three sections that encompass survey data on owners' decisions about their conventional (i.e., gasoline) vehicles, as well as more fuel-efficient and advanced-technology vehicles.

\subsection{VEHICLE OWNERS' DECISIONS ON CONVENTIONAL VEHICLES}

Q4.1.1: Which of the following attributes would be MOST important to you in your choice of your next vehicle? (closed-ended)

Table 4.1.1. Trends in Vehicle-Attribute Preference (selected years, 1980-2004)

\begin{tabular}{|l|r|r|r|r|r|r|r|r|r|r|}
\hline & \multicolumn{4}{|c|}{ J.D. Power (percent) } & \multicolumn{5}{|c|}{ ORC (percent) } \\
\hline Attributes & $\mathbf{1 9 8 0}$ & $\mathbf{1 9 8 1}$ & $\mathbf{1 9 8 3}$ & $\mathbf{1 9 8 5}$ & $\mathbf{1 9 8 7}$ & $\mathbf{1 9 9 6}$ & $\mathbf{1 9 9 8}$ & $\mathbf{2 0 0 0}$ & $\mathbf{2 0 0 1}$ & $\mathbf{2 0 0 4}$ \\
\hline Fuel economy & 42 & 20 & 13 & 8 & 4 & 7 & 4 & 10 & 10 & 22 \\
\hline Dependability & 31 & 40 & 38 & 41 & 44 & 34 & 36 & 32 & 29 & 26 \\
\hline Low price & 14 & 21 & 30 & 29 & 31 & 11 & 5 & 11 & 8 & 10 \\
\hline Quality & 4 & 7 & 11 & 12 & 8 & 19 & 20 & 21 & 22 & 19 \\
\hline Safety & 9 & 12 & 9 & 10 & 14 & 29 & 34 & 24 & 29 & 23 \\
\hline $\begin{array}{l}\text { Don't know/ } \\
\text { none of these }\end{array}$ & & & & & & & 1 & 2 & 1 & \\
\hline Total & 100 & 100 & 100 & 100 & 101 & 100 & 100 & 100 & 99 & 100 \\
\hline
\end{tabular}

Sources: For 1980s: J. D. Power (data based on new-car buyers). For 1996: ORC for NREL. For 1998: ORC for NREL (1998a), $N=1,000$. For 2000: ORC for NREL (2000a), $\mathrm{N}=$ 941. For 2001: ORC for NREL (2001c), $\mathrm{N}=989$. For 2001: ORC for NREL (2004a), $\mathrm{N}=949$.

In-market car buyers were asked about their views toward sport utility vehicles (SUVs).

Table 4.1.2. Issue Is a Major Reason for Those NOT Considering the Purchase of an SUV (2003)

\begin{tabular}{|l|c|c|}
\hline Issue & $\begin{array}{c}\text { January } \\
\mathbf{2 0 0 3}\end{array}$ & $\begin{array}{c}\text { March } \\
\mathbf{2 0 0 3}\end{array}$ \\
\hline Price of gas & $*$ & 50 \\
\hline Not the kind of vehicle I want & 51 & 45 \\
\hline Rollover/safety concerns & 30 & 34 \\
\hline Impact on foreign oil dependence & 28 & 31 \\
\hline Impact on environment & 25 & 26 \\
\hline Too big for the road & 23 & 23 \\
\hline
\end{tabular}

Source: Kelley Blue Book (2003), N=524

* Question not asked in first wave 


\subsection{VEHICLE OWNERS' DECISIONS ABOUT MORE FUEL-EFFICIENT VEHICLES}

Q4.2.1: $\quad$ Suppose that the next vehicle you've decided to buy offers an option of better fuel economy, but at a higher price. The savings in fuel costs would pay back the higher price over time. How soon, in years, would the fuel savings have to pay back the additional cost to persuade you to buy the higher fuel-economy option?

Table 4.2.1. Number of Years Public is Willing to Accept for Payback of Higher Fuel-Economy Vehicle (2002)

\begin{tabular}{|l|r|}
\hline Years & Percent \\
\hline 1 & 18 \\
\hline 2 & 23 \\
\hline 3 & 13 \\
\hline 4 & 3 \\
\hline 5 & 12 \\
\hline 6 & - \\
\hline More than 6 & 3 \\
\hline Don't Know & 27 \\
\hline Total & 100 \\
\hline Mean & 2.9 \\
\hline
\end{tabular}

Source: ORC for NREL (2002b), N=1,000

Q4.2.2: How much more would you be willing to pay for the vehicle that gets $10 \%$ better fuel economy than for the vehicle you currently drive?

Table 4.2.2. Additional Amount the Public is Willing to Pay for a Vehicle with a 10 Percent Increase in Fuel Economy (2001)

\begin{tabular}{|l|r|}
\hline Dollar Amount & Percent \\
\hline Less than $\$ 500$ & 7 \\
\hline$\$ 500-\$ 1,000$ & 15 \\
\hline$\$ 1,001-\$ 2,500$ & 17 \\
\hline$\$ 2,501-\$ 5,000$ & 15 \\
\hline More than \$5,000 & 5 \\
\hline Nothing more & 18 \\
\hline Don't know & 23 \\
\hline Total & 100 \\
\hline Mean 1 (including none) & $\$ 2,143$ \\
\hline Mean ${ }^{1}$ (excluding none) & $\$ 2,799$ \\
\hline
\end{tabular}

Source: ORC for NREL (2001b), Study No. 710449, N=180

${ }^{1}$ In this report, calculation of means, medians, and standard deviations are based on raw numbers. "Don't know" responses are not part of the calculations. 
Q4.2.3: Suppose you have decided to buy a new vehicle and have a choice of an optional engine that requires a new fuel that costs the same as gasoline and is just as good as gasoline.

Version A: The optional engine costs the same as the conventional one but gets $50 \%$ more miles per gallon. However, the fuel it requires is sold only at 1 in 10 stations. Which would you most likely buy?

Version B: The optional engine costs the same as the conventional one but gets $50 \%$ more miles per gallon. However, the fuel it requires is sold only at 1 in 5 stations. Which would you most likely buy?

Version C: The optional engine costs the same as the conventional one but gets $50 \%$ more miles per gallon. However, the fuel it requires is sold only at 1 in 3 stations. Which would you most likely buy?

Table 4.2.3. Public Preference Toward Purchasing a More Fuel-Efficient Engine with Different Fuel-Availability Options (2000)

\begin{tabular}{|c|l|c|c|c|}
\hline \multicolumn{2}{|c|}{ Fuel-Availability Options } & $\begin{array}{c}\text { Conventional } \\
\text { Engine } \\
\text { (percent) }\end{array}$ & $\begin{array}{c}\text { Optional } \\
\text { Engine } \\
\text { (percent) }\end{array}$ & $\begin{array}{c}\text { Don't } \\
\text { Know/Refused } \\
\text { (percent) }\end{array}$ \\
\hline A & $\begin{array}{l}\text { The optional engine costs the same as } \\
\text { the conventional one, but gets 50\% } \\
\text { more miles per gallon. However, the } \\
\text { fuel it requires is sold only at 1 in 10 } \\
\text { stations. }\end{array}$ & 66 & 30 & 4 \\
\hline B & $\begin{array}{l}\text { The optional engine costs the same as } \\
\text { the conventional one, but gets 50\% } \\
\text { more miles per gallon. However, the } \\
\text { fuel it requires is sold only at 1 in 5 } \\
\text { stations. }\end{array}$ & 62 & 36 & 3 \\
\hline C & $\begin{array}{l}\text { The optional engine costs the same as } \\
\text { the conventional one, but gets 50\% } \\
\text { more miles per gallon. However, the } \\
\text { fuel it requires is sold only at 1 in 3 } \\
\text { stations. }\end{array}$ & 43 & 53 & 4 \\
\hline
\end{tabular}

Source: ORC for NREL (2000d), Study No. 70920, N=111 


\subsection{VEHICLE OWNERS' DECISIONS ABOUT ADVANCED-TECHNOLOGY VEHICLES}

\section{Hybrid-Electric Vehicles}

Q4.3.1: There are some cars in the U.S. market today that have advanced hybrid-electric power trains that combine a small electric motor and a small gasoline engine to achieve a higher fuel economy than similar cars. How much have you heard about this technology: a great deal, some, very little, or nothing?

Table 4.3.1. Amount of Information Heard Pertaining to Advanced Hybrid-Electric Power Trains (2000-02)

\begin{tabular}{|l|c|c|c|}
\hline \multirow{2}{*}{} & \multicolumn{3}{|c|}{ Percent } \\
\cline { 2 - 4 } & August 2000 & November 2001 & November 2002 \\
\hline A Great Deal & 13 & 10 & 20 \\
\hline Some & 33 & 33 & 35 \\
\hline Very Little & 34 & 30 & 26 \\
\hline Nothing & 20 & 26 & 18 \\
\hline Don't Know & 0 & 2 & 1 \\
\hline
\end{tabular}

Source: ORC for NREL (2000) N=953, (2001) N=999, (2002c) N=999

Q4.3.2: $\quad$ Please name one of these hybrid-electric cars if you can.

Table 4.3.2. Names of Advanced Hybrid-Electric Vehicles Known by the Public (selected years, 2000-04)

\begin{tabular}{|l|c|c|c|c|}
\hline \multirow{2}{*}{} & \multicolumn{4}{|c|}{ Percent } \\
\cline { 2 - 5 } & \multirow{2}{*}{ August 2000 } & November 2001 & November 2002 & May 2004 \\
\hline Any vehicle & 36 & 44 & 51 & 48 \\
\hline Honda & 15 & 24 & 24 & 17 \\
\hline Toyota & 4 & 11 & 10 & 6 \\
\hline Ford & NA & NA & NA & 4 \\
\hline Other & 14 & 6 & 7 & 52 \\
\hline Don't Know & 64 & 56 & 48 & 9 \\
\hline
\end{tabular}

Source: ORC for NREL (2000) N=953, (2001) N=999, (2002c) N=999, (2000a) N=1,000, (2004a) $\mathrm{N}=1,000$

Note: Percentages do not total 100, because each respondent could volunteer more than one response. 
A 2003 survey of in-market consumers by Kelley Blue Book examined the influence of the media on attitudes toward SUVs. Although no hybrid-electric SUVs were available in the United States at the time of this survey (mid-2003), shoppers would think favorably of such an option and might be more likely to consider the purchase of an SUV.

Table 4.3.3 Public's Attitudes Toward Hybrid-Electric SUVs (2003)

\begin{tabular}{|l|r|r|r|r|r|r|}
\hline & \multicolumn{6}{|c|}{ Percent } \\
\cline { 2 - 8 } & \multicolumn{2}{|c|}{ SUV Considerers } & \multicolumn{2}{c|}{$\begin{array}{c}\text { SUV } \\
\text { Non-Considerers }\end{array}$} & \multicolumn{2}{c|}{ Total } \\
\cline { 2 - 8 } & Jan 2003 & Mar 2003 & Jan 2003 & Mar 2003 & Jan 2003 & Mar 2003 \\
\hline $\begin{array}{l}\text { More favorable } \\
\text { toward SUVs }\end{array}$ & 52 & 46 & 45 & 44 & 48 & 45 \\
\hline Neutral & 40 & 46 & 44 & 51 & 42 & 49 \\
\hline $\begin{array}{l}\text { Less favorable } \\
\text { toward SUVs }\end{array}$ & 8 & 7 & 11 & 5 & 10 & 6 \\
\hline
\end{tabular}

Source: Kelley Blue Book (2003), N=524 


\section{Diesel Vehicles}

Q4.3.4: Would you consider buying a diesel engine version that got $40 \%$ better fuel economy and costs an additional $\$ 1,500$ ?

Table 4.3.4.1 Public's Willingness to Consider the Purchase of a Diesel Engine With a 40 Percent Increase in Fuel Economy and Additional Costs of \$1,500 (1997)

\begin{tabular}{|l|r|}
\hline Considerations of Diesel-Engine Options & Percent \\
\hline $\begin{array}{l}\text { Would not consider buying a diesel engine version that got 40\% better } \\
\text { fuel economy and costs an additional \$1,500. }\end{array}$ & 75 \\
\hline $\begin{array}{l}\text { Would consider buying a diesel-engine version that got 40\% better } \\
\text { fuel economy and costs an additional \$1,500. }\end{array}$ & 21 \\
\hline Don't know & 4 \\
\hline Total & 100 \\
\hline
\end{tabular}

Source: ORC for NREL (1997), Study No. 70627, N=1,010

Table 4.3.4.2 Public's Willingness to Pay a Premium for a Clean Diesel Engine (2002)

\begin{tabular}{|l|r|l|r|}
\hline \multirow{2}{*}{$\begin{array}{l}\text { Premium Willing to Pay } \\
\text { For Clean Diesel }\end{array}$} & \multicolumn{3}{|c|}{ Percent } \\
\cline { 2 - 4 } & Total & $\begin{array}{l}\text { Current Diesel } \\
\text { Owner }\end{array}$ & $\begin{array}{l}\text { Current Gas } \\
\text { Owner }\end{array}$ \\
\hline$\$ 0$ & 33 & 10 & 34 \\
\hline$\$ 1-\$ 199$ & 8 & 4 & 8 \\
\hline$\$ 200-\$ 399$ & 7 & 1 & 7 \\
\hline$\$ 400-\$ 599$ & 16 & 8 & 17 \\
\hline$\$ 600-\$ 999$ & 4 & 3 & 4 \\
\hline$\$ 1,000-\$ 1,499$ & 14 & 17 & 14 \\
\hline$\$ 1,500-\$ 1,999$ & 4 & 5 & 4 \\
\hline More than $\$ 2,000$ & 14 & 51 & 12 \\
\hline
\end{tabular}

Source: J.D. Power and Associates (2002), N-not available 
Q4.3.5: Assume that a new vehicle you want to buy has two engine options that are equally clean, dependable, powerful, odorless, and smooth running. One uses gasoline and the other uses diesel fuel and gets $40 \%$ more miles per gallon but costs $\$ 2,000$ more. Which engine option would you buy?

Table 4.3.5. Purchase Preference Between Diesel and Gasoline Vehicles by Vehicle Type (2001)

\begin{tabular}{|c|c|c|c|c|c|c|c|}
\hline \multirow{3}{*}{ Vehicles } & \multicolumn{7}{|c|}{ Percent } \\
\hline & \multirow[b]{2}{*}{ Total } & \multicolumn{5}{|c|}{ Vehicle Type } & \multirow{2}{*}{$\begin{array}{l}\text { Don't } \\
\text { Know } \\
\text { Which } \\
\text { Type of } \\
\text { Vehicle } \\
\text { to Buy }\end{array}$} \\
\hline & & Small Car & $\begin{array}{l}\text { Large } \\
\text { Car }\end{array}$ & Minivan & SUV & $\begin{array}{c}\text { Pickup/ } \\
\text { Van }\end{array}$ & \\
\hline Gasoline & 71 & 75 & 81 & 71 & 62 & 65 & 60 \\
\hline Diesel & 27 & 21 & 18 & 27 & 37 & 34 & 28 \\
\hline Don't know & 2 & 4 & 1 & 2 & 1 & 1 & 12 \\
\hline Total & 100 & 100 & 100 & 100 & 100 & 100 & 100 \\
\hline
\end{tabular}

Source: ORC for NREL (2001c), Study No. 710288, N=989

If chose diesel, ask:

Q4.3.6: Why did you choose the diesel option?

Table 4.3.6. Reasons for Choosing a Diesel Option (2001)

\begin{tabular}{|l|r|}
\hline Reasons & Percent \\
\hline $\begin{array}{l}\text { Fuel economy (better gas mileage/fuel economy, 40\% better mileage/miles } \\
\text { per gallon) }\end{array}$ & 46 \\
\hline $\begin{array}{l}\text { Cost (saves money/pays for itself over time, cheaper than gasoline, } \\
\text { economical) }\end{array}$ & 34 \\
\hline Dependability (diesel engine lasts longer, more reliable/dependable) & 12 \\
\hline Environmental (burns cleaner, other related mentions) & 10 \\
\hline I have/drive vehicle with diesel engine & 3 \\
\hline More power/horsepower & 3 \\
\hline Previous positive experience/ satisfied with diesel & 10 \\
\hline Other /don't know & \\
\hline
\end{tabular}

Source: ORC for NREL (2001c), Study No. 710288, N=266

Note: Percentages do not total 100, because each respondent could volunteer more than one response. 
If did not choose diesel, ask:

Q4.3.7: Why did you reject the diesel option?

Table 4.3.7. Reasons for Rejecting a Diesel Option (2001)

\begin{tabular}{|l|r|}
\hline Reasons & Percent \\
\hline $\begin{array}{l}\text { Environmental (pollutes the air, odor/smell/stink, too much noise, other } \\
\text { related mentions) }\end{array}$ & 39 \\
\hline Cost (expense, initial cost/\$2,000 more, other related mentions ) & 19 \\
\hline Lack of fuel availability & 17 \\
\hline Don't know enough/know nothing about it/never owned one & 11 \\
\hline Engine problems (difficult to start in winter, other related mentions) & 8 \\
\hline Just don't like diesel/husband doesn't like diesel & 7 \\
\hline Prefer/used to/satisfied with gasoline & 4 \\
\hline Negative experience & 3 \\
\hline Difficult to maintain/repair & 4 \\
\hline Other & 4 \\
\hline Don't know & \\
\hline
\end{tabular}

Source: ORC for NREL (2001c), Study No. 710288, N=723

\section{General Preferences}

Q4.3.8: Which one of the following are you planning to purchase for your next household vehicle?

Table 4.3.8. Vehicle-Purchase Preferences (2004)

\begin{tabular}{|l|c|}
\hline Type of Vehicle & Percent \\
\hline $\begin{array}{l}\text { Large car, same size or larger than a Honda Accord, Chevy Malibu, or } \\
\text { Toyota Camry }\end{array}$ & 28 \\
\hline SUV or sport utility vehicle & 23 \\
\hline Small car, smaller than a Honda Accord, Chevy Malibu, or Toyota Camry & 20 \\
\hline Pickup truck or large van & 6 \\
\hline Minivan & 4 \\
\hline Other/ don't know & 99 \\
\hline Total & 6 \\
\hline
\end{tabular}

Source: ORC for NREL (2004a), Study No. 713218, N=1,000 
Q4.3.9: When you purchase your next household vehicle, how likely are you to buy each of the following?

Would you say you definitely will buy it, you would be very likely to buy it, you would be likely to buy it, you would be likely to buy it, you would be not likely to buy it or you definitely won't buy it?

Table 4.3.9. Vehicle-Purchase Preferences - Diesel vs. Hybrid-electric (2004)

\begin{tabular}{|l|r|r|}
\hline \multirow{2}{*}{ Type of Vehicle } & \multicolumn{2}{|c|}{ Percent } \\
\cline { 2 - 3 } & $\begin{array}{c}\text { Hybrid- } \\
\text { electric }\end{array}$ & Diesel \\
\hline Definitely will buy & 7 & 4 \\
\hline Very likely to buy & 8 & 4 \\
\hline Likely to buy & 27 & 14 \\
\hline Not likely to buy & 31 & 36 \\
\hline Definitely won't buy & 20 & 38 \\
\hline Don't know & 6 & 3 \\
\hline Total & 99 & 99 \\
\hline
\end{tabular}

Source: ORC for NREL (2004a), Study No. 713218, N=1,000

Q4.3.10: $\quad$ Suppose you were given an extra $\$ 1,000$ that you must spend on acceleration, fuel economy and/or the ability to tow, when buying your next vehicle. How much would you spend on each attribute? You can spend all the money on one attribute or split it among two or three attributes.

Table 4.3.10. Priority on Vehicle Attributes (2004)

\begin{tabular}{|l|r|}
\hline Attribute & Dollars \\
\hline Fuel economy & $\$ 609$ \\
\hline Acceleration & $\$ 248$ \\
\hline Ability to tow & $\$ 143$ \\
\hline Total & $\$ 1,000$ \\
\hline
\end{tabular}

Source: ORC for NREL (2004a), Study No. 713218, N=1,000 


\section{TRAFFIC ISSUES}

With more vehicles on the roads and each vehicle traveling more miles each year, it is not surprising that traffic congestion is becoming a problem in many locations throughout the country. A study by the Texas Transportation Institute reported that the average American spends 36 hours per year stuck in traffic. These survey questions look at various traffic issues and the public's responses to dealing with them.

Q5.1: What part of driving do you find most irritating? (open-ended)

Table 5.1. Public Ranking of the Most Irritating Part of Driving (2002)

\begin{tabular}{|l|c|}
\hline Most Irritating Part of Driving & Percent \\
\hline Traffic congestion & 40 \\
\hline Other drivers & 31 \\
\hline Cost & 12 \\
\hline Road conditions & 10 \\
\hline Other/ don't know & 7 \\
\hline Total & 100 \\
\hline
\end{tabular}

Source: ORC (2002), N=1,005

Travelers who reported trip delays were asked to name the main reason for the delays.

Table 5.2. Most Important Reasons for Travel Delays (2000)

\begin{tabular}{|l|c|}
\hline Reason for Trip Delay & Percent \\
\hline Heavy traffic & 53 \\
\hline Roadwork & 26 \\
\hline Accidents & 10 \\
\hline Traffic signals & 10 \\
\hline
\end{tabular}

Source: FHWA Operations and Planning/Environment Survey (2000)

Q5.3: Which of the following best describes your view of the traffic you encounter in your area every day?

Table 5.3. Public's View of Daily Traffic (2000)

\begin{tabular}{|l|c|}
\hline Best Describes Daily Traffic & Percent \\
\hline Not a significant problem & 48 \\
\hline Minor inconvenience and problem & 31 \\
\hline Major inconvenience and problem & 19 \\
\hline No opinion & 2 \\
\hline
\end{tabular}

Source: Gallup (2000), N=601 
Q5.4: Looking ahead, do you anticipate that the traffic in your area today will get much better, somewhat better, stay the same, get somewhat worse, or get much worse during the next five years?

Table 5.4. Public's View of Future Traffic (2000)

\begin{tabular}{|l|c|}
\hline Best Describes Future Traffic & Percent \\
\hline Get much better & 5 \\
\hline Get somewhat better & 10 \\
\hline Stay the same & 23 \\
\hline Get somewhat worse & 33 \\
\hline Get much worse & 28 \\
\hline No opinion & 1 \\
\hline
\end{tabular}

Source: Gallup (2000), N=601

Q5.5: Have you had to change your life or schedule in any way because of traffic in recent years? In what ways?

Table 5.5.1 Have Changed Schedule Because of Traffic (2000)

\begin{tabular}{|l|c|}
\hline & Percent \\
\hline Yes & 31 \\
\hline No & 69 \\
\hline \multicolumn{2}{|l|}{ Source: Gallup (2000), $\mathrm{N}=601$}
\end{tabular}

Table 5.5.2 Ways Public has Changed Because of Traffic (2000)

\begin{tabular}{|l|c|}
\hline Changes Because of Traffic & Percent \\
\hline Leave earlier & 36 \\
\hline Take alternate routes & 18 \\
\hline Allow more time for travel & 13 \\
\hline Avoid driving at certain times & 12 \\
\hline Don't drive as much & 7 \\
\hline Changed working hours & 6 \\
\hline Moved & 5 \\
\hline Use mass transit or carpool & 3 \\
\hline Work at home/ telecommute & 1 \\
\hline
\end{tabular}

Source: Gallup (2000), N=601 
Q5.6: How often do you get stuck driving in traffic jams?

Table 5.6. Frequency of Getting Stuck in Traffic Jams (2000)

\begin{tabular}{|l|c|}
\hline Frequency of Traffic Jams & Percent \\
\hline Every day & 11 \\
\hline Several times a week & 14 \\
\hline Several times a month & 22 \\
\hline A few times a year & 31 \\
\hline Never & 20 \\
\hline
\end{tabular}

Source: Gallup (2000), N=318

Q5.7: As opposed to other means of transportation, please tell me the main reason you used public transit last month?

Table 5.7. Reasons for Using Public Transit (2003)

\begin{tabular}{|l|c|}
\hline Reason for Using Public Transit & Percent \\
\hline $\begin{array}{l}\text { More convenient than other means of } \\
\text { transportation }\end{array}$ & 44 \\
\hline Have no vehicle available & 30 \\
\hline $\begin{array}{l}\text { Cheaper/costs less/saves money/expensive } \\
\text { parking }\end{array}$ & 15 \\
\hline Faster than other means of transportation & 4 \\
\hline Away from home on business or pleasure travel & 3 \\
\hline Parking not available & 2 \\
\hline $\begin{array}{l}\text { Less impact on the environment than other } \\
\text { means of transportation }\end{array}$ & 1 \\
\hline Other & 1 \\
\hline
\end{tabular}

Source: Bureau of Transportation Statistics (2003), N-not available 


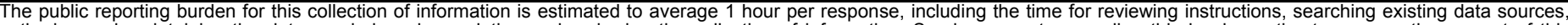

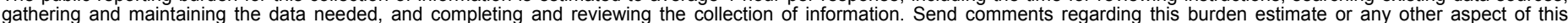

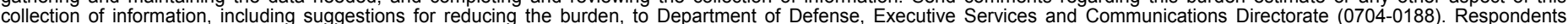

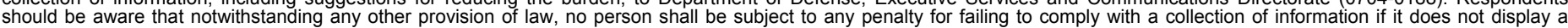

should be aware that notwithstanding

PLEASE DO NOT RETURN YOUR FORM TO THE ABOVE ORGANIZATION.

\begin{tabular}{l|l|l|l} 
1. REPORT DATE (DD-MM-YYYY) & 2. REPORT TYPE & 3. DATES COVERED (FrOm - TO)
\end{tabular}

April 2005

Technical Report

4. TITLE AND SUBTITLE

Consumer Views on Transportation and Energy (Second Edition)

5a. CONTRACT NUMBER

DE-AC36-99-G010337

5b. GRANT NUMBER

5c. PROGRAM ELEMENT NUMBER

6. AUTHOR(S)

Compiled by Michelle Kubik

5d. PROJECT NUMBER

NREL/TP-620-36785

5e. TASK NUMBER

ASA5.1315

5f. WORK UNIT NUMBER
7. PERFORMING ORGANIZATION NAME(S) AND ADDRESS(ES)

National Renewable Energy Laboratory

1617 Cole Blvd.

Golden, CO 80401-3393
8. PERFORMING ORGANIZATION REPORT NUMBER

NREL/TP-620-36785

9. SPONSORING/MONITORING AGENCY NAME(S) AND ADDRESS(ES)

10. SPONSOR/MONITOR'S ACRONYM(S)

NREL

11. SPONSORING/MONITORING AGENCY REPORT NUMBER

12. DISTRIBUTION AVAILABILITY STATEMENT

National Technical Information Service

U.S. Department of Commerce

5285 Port Royal Road

Springfield, VA 22161

13. SUPPLEMENTARY NOTES

14. ABSTRACT (Maximum 200 Words)

This report has been assembled to provide the Office of Energy Efficiency and Renewable Energy (EERE) with an idea of how the American public views various transportation, energy, and environmental issues. The data presented in this report have been drawn from multiple sources: surveys conducted by the Opinion Research Corporation (ORC) for the National Renewable Energy Laboratory (NREL) that are commissioned and funded by EERE, Gallup polls, and other sources.

\section{SUBJECT TERMS}

analysis; transportation; consumers; gasoline; fuel; foreign oil dependence; sport utility vehicles; SUVs; fuel-efficiency vehicles; travel; traffic; ethanol; hybrid-electric vehicles; advanced-technology vehicles; greenhouse gas emissions; Elyse Steiner; Philip Patterson; Michelle Kubik; Transportation Energy Survey Data Book

\begin{tabular}{|l|l|l|l|l|}
\hline $\begin{array}{l}\text { 16. SECURITY CLASSIFICATION OF: } \\
\begin{array}{l}\text { a. REPORT } \\
\text { Unclassified }\end{array}\end{array}$ & $\begin{array}{c}\text { b. ABSTRACT } \\
\text { Unclassified }\end{array}$ & $\begin{array}{l}\text { c. THIS PAGE } \\
\text { Unclassified }\end{array}$ & $\begin{array}{c}\text { OF ABSTRACT } \\
\text { UL }\end{array}$ & $\begin{array}{c}\text { 18. NUMBER } \\
\text { OF PAGES }\end{array}$ \\
& & &
\end{tabular}

19a. NAME OF RESPONSIBLE PERSON

19b. TELEPHONE NUMBER (Include area code) 